Discussion Paper No. 10-025

Loan Availability and Investment Can Innovative Companies Better Cope with Loan Denials?

Elisabeth Mueller and Frank Reize

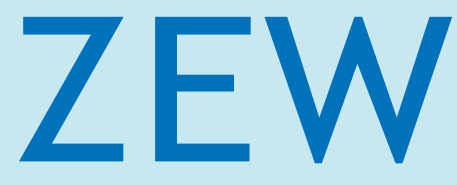

Zentrum für Europäische Wirtschaftsforschung $\mathrm{GmbH}$

Centre for European Economic Research 
Discussion Paper No. 10-025

\title{
Loan Availability and Investment - Can Innovative Companies Better Cope with Loan Denials?
}

\author{
Elisabeth Mueller and Frank Reize
}

Download this ZEW Discussion Paper from our ftp server:

ftp://ftp.zew.de/pub/zew-docs/dp/dp10025.pdf

Die Discussion Papers dienen einer möglichst schnellen Verbreitung von neueren Forschungsarbeiten des ZEW. Die Beiträge liegen in alleiniger Verantwortung der Autoren und stellen nicht notwendigerweise die Meinung des ZEW dar.

Discussion Papers are intended to make results of ZEW research promptly available to other economists in order to encourage discussion and suggestions for revisions. The authors are solely responsible for the contents which do not necessarily represent the opinion of the ZEW. 


\section{Non-technical Summary}

Access to external financing is of high importance to companies for the financing of fixed investments. Investment in fixed assets occurs in irregular intervals and requires relatively large amounts of financing, whereas internal financing from cash flow accrues more continuously. For large investment projects internal financing is therefore unlikely to be sufficient. Bank financing is especially important for small and medium-sized enterprises (SMEs), because they have no access to either the public equity market or to the corporate bond market. When companies apply for loans they are not sure whether they will actually receive financing. So far, little is known about how companies adjust their investment volume in case desired loans turn out to be unavailable. It is also not known which financing mix companies choose for the investment they are able to realize.

Our main focus is on differences between innovative and non-innovative companies. Whereas debt financing is less well suited for innovative companies due to the higher uncertainty regarding their returns, equity financing has the advantage of the financier participating in the upside potential of the company. Innovative companies may be better able to cope with loan denials if they are able to substitute external equity for unavailable bank loans.

The analysis is based on an annual company survey conducted by KfW Bankengruppe that is representative of German SMEs. We build on more than 4,500 observations relating to the years 2005 to 2007. The survey is unique in that it provides detailed information on planned investment, actual investment, experience with loan applications and innovative activities. Econometrically we control for the non-randomness of loan denials by estimating a selection equation for loan denials. We use the intensity of banking competition at the district level as an exclusion restriction to ensure identification is not only based on functional form assumptions.

We find that innovative companies can better cope with loan denials. Compared with noninnovators, innovators can realize additional 10.0 percentage points of the share of actual to planned investment when facing a loan denial. By investigating the mix of financing sources that companies ultimately use to finance their actual investment, we provide an explanation for the better performance. Innovative companies that experience a loan denial have the ability to increase the share of external equity in their financing mix. Facing a loan denial, innovators finance $6.7 \%$ of their investment with external equity compared with only $1.1 \%$ for non-innovators. External equity includes business angel financing, venture capital, and equity investment of new owners. Innovative companies may be turned down by banks because debt is not the optimal type of financing for them. If their investment projects are profitable, however, they may be able to attract equity investors. 


\section{Das Wichtigste in Kürze}

Der Zugang zu externer Finanzierung ist für die Investitionsfinanzierung von Unternehmen von großer Bedeutung. Für Investitionen sind in größeren Abständen hohe Beträge erforderlich, wohingegen Mittel aus der Innenfinanzierung kontinuierlich zufließen. Für umfangreiche Investitionsvorhaben ist eine alleinige Innenfinanzierung meistens nicht ausreichend. Für kleine und mittlere Unternehmen (KMU) ist eine Finanzierung durch Banken besonders wichtig, da KMU keinen Zugang zur Börse oder zum Markt für Unternehmensanleihen haben. Wenn Unternehmen einen Kreditantrag stellen, können sie nicht sicher sein, ob er letztendlich genehmigt wird. Bislang ist nur wenig darüber bekannt, wie Unternehmen ihr Investitionsvolumen anpassen, wenn ihre Kreditanträge von den Banken abgelehnt werden. Ebenso ist nicht bekannt, welche Finanzierungsquellen Unternehmen für Investitionen wählen, wenn sie trotz Kreditablehnung in der Lage sind zu investieren.

Der Schwerpunkt der Analyse liegt auf Unterschieden zwischen innovativen und nichtinnovativen Unternehmen. Während eine Kreditfinanzierung für innovative Unternehmen durch die höhere Unsicherheit in ihren Erträgen weniger gut geeignet ist, hat die Eigenkapitalfinanzierung den Vorteil, dass der Investor im Erfolgsfall an den Erträgen partizipiert. Innovative Unternehmen können Kreditabsagen möglicherweise besser bewältigen als nicht-innovative Unternehmen, wenn sie nach erfolglosen Kreditverhandlungen zusätzliches Eigenkapital aufnehmen können.

Die Analyse basiert auf einer jährlichen Unternehmensbefragung der KfW-Bankengruppe, die repräsentativ für den deutschen Mittelstand ist. Mehr als 4500 Beobachtungen mit Informationen für die Jahre 2005 bis 2007 stehen zur Verfügung. Diese Umfrage enthält Informationen über geplante Investitionen, tatsächliche Investitionen, Kreditverhandlungen und Innovationsaktivitäten. Ökonometrisch kontrollieren wir für den Einfluss unbeobachtbarer Unternehmenseigenschaften auf den Ausgang von Kreditverhandlungen mit einer Selektionsgleichung. Wir verwenden die Intensität des Bankenwettbewerbs auf Kreisebene als Ausschlussrestriktion, damit die Identifikation des statistischen Modells nicht nur auf Annahmen zur funktionalen Form beruht.

Unsere Ergebnisse zeigen, dass innovative Unternehmen Kreditabsagen besser verkraften können. Verglichen mit Nicht-Innovatoren können Innovatoren im Fall einer Kreditablehnung zusätzliche 10,0 Prozentpunkte des Anteils von tatsächlichen zu geplanten Investitionen realisieren. Bei der Untersuchung der Zusammensetzung der Finanzierungsquellen, die Unternehmen letztlich für ihre realisierten Investitionen verwenden, finden wir eine Erklärung für das bessere Abschneiden. Von Banken abgelehnte innovative Unternehmen haben die Fähigkeit, den Anteil der externen Eigenkapitalfinanzierung zu erhöhen. Sie finanzieren 6,7 \% des Finanzierungsbedarfs mit externem Eigenkapital, während es bei von Banken abgelehnten Nicht-Innovatoren lediglich 1,1\% sind. Externe Eigenkapitalfinanzierung umfasst die Finanzierung durch Business Angels, Wagniskapital und Eigenkapitalbeteiligungen zusätzlicher Eigentümer. Innovative Unternehmen werden möglicherweise von Banken abgelehnt, da Kredite keine optimale Finanzierungsform für sie darstellen. Wenn ihre Investitionsprojekte profitabel sind, können sie jedoch teilweise neue Eigenkapitalinvestoren gewinnen. 


\title{
Loan Availability and Investment -
}

\section{Can Innovative Companies Better Cope with Loan Denials?}

\author{
Elisabeth Mueller* and Frank Reize**
}

April 15, 2010

\begin{abstract}
This study examines the consequences of loan denials for the investment performance of small and medium-sized German enterprises. As a consequence of a loan denial, innovative companies experience a smaller drop in the share of actual to planned investment than non-innovative companies. The non-randomness of loan denials is controlled for with a selection equation employing the intensity of banking competition at the district level as an exclusion restriction. We can explain the better performance of innovative companies by their ability to increase the use of external equity financing, such as venture capital or mezzanine capital, when facing a loan denial.
\end{abstract}

Keywords: Investment, loan availability, innovation, private equity

JEL Classification: G21, G31, O32

* Dr. Elisabeth Mueller, Centre for European Economic Research (ZEW), L7,1, 68161

Mannheim, Germany, mueller@zew.de

** Dr. Frank Reize, KfW Bankengruppe, Palmengartenstraße 5-9, 60325 Frankfurt am Main, Germany, frank.reize@kfw.de

Acknowledgements: We would like to thank Christian Rammer, Tereza Tykvova and Volker Zimmermann for helpful discussions. This paper benefitted from comments of seminar participants at the Frankfurt School of Finance and Management, Frankfurt am Main, Germany and at ZEW, Mannheim, Germany. We would like to thank Sabine Neumann for research assistance. 


\section{Introduction}

Access to external financing is of high importance to companies for the financing of fixed investments. Investment in fixed assets occurs in irregular intervals and requires relatively large amounts of financing, whereas internal financing from cash flow accrues more continuously. For large investment projects internal financing is therefore unlikely to be sufficient. Bank financing is especially important for small and medium-sized enterprises (SMEs), because they have no access to either the public equity market or to the corporate bond market. For example, Berger and Udell (1998) find for US small businesses that bank loans are with $27 \%$ of total financing the most important external source of financing. For German SMEs, Reize (2007) finds an even higher share for bank loans at 31\%. When companies apply for loans they are not sure whether they will actually receive financing. So far, little is known about how companies adjust their investment volume in case desired loans turn out to be unavailable. It is also not known which financing mix companies choose for the investment they are able to realize.

In this paper we investigate to which degree companies adjust their plans for fixed investment downwards if they are confronted with a loan denial. Our main focus is on differences between innovative and non-innovative companies. Whereas debt financing is less well suited for innovative companies due to the higher uncertainty regarding their returns, equity financing has the advantage of the financier participating in the upside potential of the company. Innovative companies may be better able to cope with loan denials if they are able to substitute external equity for unavailable bank loans. We also investigate how companies ultimately finance their actual investment if bank loans are not available. Two different concepts of an innovative company are employed. Based on an outcome measure, a company is an innovator if it has introduced a new product or a new process in the last three years. Using an input measure, companies are classified as innovative if they conduct either continuous or occasional research and development (R\&D).

Our analysis is based on an annual company survey conducted by KfW Bankengruppe that is representative of German SMEs. We build on more than 4,500 observations relating to the years 2005, 2006 and 2007. The survey is unique in that it provides detailed information on planned investment, actual investment, experience with loan applications and innovative activities. 
It is fitting to study these questions for Germany, because the German financial system is bank-based as opposed to market-based, so banks are of especially high importance for the financing of companies. The German financial system is characterized by close, long-term relationships between banks and SMEs. Companies typically have a main bank that acts as premier lender and offers most banking services to the company (Audretsch and Elston, 2002). As result of the bank-based system, companies rely heavily on bank loans and have traditionally a low equity ratio (Delbreil et al., 2005).

We find that innovative companies can better cope with loan denials. Compared with noninnovators, innovators can realize additional 10.0 percentage points of the share of actual to planned investment when facing a loan denial. By investigating the mix of financing sources that companies ultimately use to finance their actual investment we provide an explanation for the better performance. Innovative companies that experience a loan denial have the ability to increase the share of external equity in their financing mix. Facing a loan denial, innovators finance $6.7 \%$ of their investment with external equity compared with only $1.1 \%$ for noninnovators. External equity includes business angel financing, venture capital, and equity investment of new owners. Innovative companies may be turned down by banks because debt is not the optimal type of financing for them. If their investment projects are profitable, however, they may be able to attract equity investors.

Econometrically we control for the non-randomness of loan denials by estimating a selection equation for loan denials. We use the intensity of banking competition at the district level as an exclusion restriction to ensure identification is not only based on functional form assumptions.

Our paper is related to two strands of the literature. The first strand investigates the relationship between the availability of bank loans and the investment performance of companies. Gan (2007a) sheds light on this relationship from the perspective of the company. Using the real estate crisis of Japan as natural experiment, she finds that companies with larger drops in collateral value find it more difficult to sustain lending relationships, have smaller credit growth and have smaller investment intensity (investment/total assets). More typically, this relationship is analyzed from the perspective of the bank. Gibson (1995) and Gan (2007b) find for Japanese companies that their investment volume is lower if the financial health of their main bank is weaker. These results suggests that companies may not be able to realize all profitable investment opportunities if access to bank loans is restricted. Using differences in an industry's dependence on external financing, Dell' Ariccia et al. 
(2008) show that in times of banking crises company investment contracts more in sectors more dependent on external financing. Hancock and Wilcox (1998) use the period of the credit crunch in the US in the early 1990s to investigate the influence of loan volume on real economic activity at the state level. Their results show that the total loan volume at small banks has a larger influence on the employment of small companies than does the loan volume at large banks. Small companies often have bank relationships with small banks and cannot easily switch to other sources of financing should their main bank find itself in difficulty.

The second strand to which our paper relates is the literature on financial constraints, which documents the role of the availability of internal financing for the investment behavior of companies. Hubbard (1998) provides a survey of this literature. The studies generally find that companies that are a priori believed to be more financially constrained have higher investment-cash flow sensitivities. Hall (1992) and Himmelberg and Petersen (1994) provide an extension by also investigating the role of cash flow for R\&D expenditures. These papers find a significant relationship between cash flow and both general investment and R\&D expenditures for US companies. Exploiting direct survey evidence to identify financing constraints, Winker (1999) documents a negative influence of financing constraints on investment and innovation expenditures for German companies. Also using direct survey evidence, Hottenrott and Peters (2009) find that companies with high innovative capability are more likely to be constrained in their innovative investments due to larger resource requirements. Some studies also investigate the role of access to external capital for realized investment. However, these studies do not use direct evidence on access to bank loans, but rely on credit ratings as a proxy for access (see, for example, Czarnitzki, 2006). ${ }^{1}$

We extend the literature on the relationship between the availability of bank loans and the investment performance of companies by investigating theoretically expected differences between innovative and non-innovative companies. We provide direct insight into how loan denials affect companies by observing differences in planned and actual investment. By directly observing loan demand we extend the literature on financial constraints which is based on indirect evidence on the availability of external financing. Companies demonstrate with their loan application that they require external funding and that they generally think that bank financing is an appropriate source. A further advantage of our approach is that it allows

\footnotetext{
${ }^{1}$ Direct evidence on access to bank loans is also used by studies showing that innovative companies are more likely to experience loan denials (see, for example, Guiso (1998) for high-tech companies and Freel (2007) for companies with high R\&D expenditures).
} 
us to directly quantify the effects of loan denials on the share of actual to planned investment. The investment-cash flow sensitivities do not allow for a direct calculation of the magnitude of the effect of higher costs of external financing for investment. To our knowledge this is the first paper to document the financing mix chosen by companies facing and not facing loan denials.

The remaining paper is organized as follows: Section 2 presents the theoretical framework and develops the hypotheses; Section 3 explains the methodology; Section 4 describes the data; Section 5 presents the empirical analysis; and Section 6 concludes.

\section{Theoretical Framework}

Modigliani and Miller (1958) show that in perfect capital markets the investment volume of companies is independent of their capital structure. Different forms of financing are perfect substitutes and companies will always realize all projects with positive net present value. In reality, however, the Modigliani-Miller theorem is unlikely to hold, because financial markets are characterized by asymmetric information. Different forms of financing are not perfect substitutes and may differ in their adequacy for different companies, depending on the companies’ characteristics.

For innovative companies equity financing has specific advantages compared with debt financing. Banks face special problems when appraising the quality of innovative projects (Hall, 2002). There is uncertainty concerning both technical feasibility and likely commercial success. It follows then that specialized technical know-how is necessary to judge the quality of loan applications from innovative companies. The high uncertainty is reflected in the typical return distribution of innovative companies characterized by very high returns if successful and a high probability of failure. This does not fit well with the obligation to honor regular interest rate payments of a constant amount. In addition, innovative companies have less collateral available, since a high share of $R \& D$ expenditures is used for the wages of researchers and does not increase the stock of tangible assets, such as machinery. A further difficulty, though affecting not only bank financing, is that innovative companies may be reluctant to share technological information with their financiers, since competitors may become aware of this knowledge (Bhattacharya and Ritter, 1983).

Debt financing may not be available for owners of innovative companies due to credit rationing. Innovative companies are more affected, because credit rationing is more severe if information is more asymmetric (Stiglitz and Weiss, 1981). Credit rationing can occur in 
equilibrium because it may not be profitable for banks to increase interest rates in response to excess demand for loans. A higher interest rate does not only reduce demand, it also increases the riskiness of the applicant pool. The losses due to higher default risk may outweigh the additional profits from the higher interest rate.

Different types of financiers have developed different abilities to resolve problems of asymmetric information. Banks use screening techniques and collateral requirements to reduce their risk exposure. They also collect information through long-term relationships with the companies and through the provision of several financial services to the same company. Venture capital financing reduces information asymmetry and moral hazard by employing complex contract structures, using staged investments, and being actively involved in the management of the companies (Kaplan and Stromberg, 2003; Gompers, 1995). This makes venture capital suitable for the financing of very innovative, high-risk companies, but the active involvement also makes this form of financing expensive. In general, equity investors are better able to cope with the high variance of returns of innovative companies. As residual claimants they gain from high expected returns and can therefore compensate for the higher probability of total failure. However, a precondition for investment is that expected returns are high enough to cover the costs of active engagement and of the risk of failure.

From these theoretical considerations we conclude that innovative companies should be better able to cope with loan denials, since they can more easily switch to equity financing, an alternative financing source that is especially suitable for them. There can be three underlying mechanisms contributing to this outcome:

First, it can be a strategy for companies to first try debt since it is cheaper and, if unsuccessful, try the alternative of equity financing. The pecking order theory predicts that companies with exhausted internal funds will try to get access to debt and only when the debt capacity is reached will companies consider additional equity (Myers and Majluf, 1984). Equity financing is more expensive than debt because investors need to deal with a higher degree of asymmetric information. Thus, even though equity financing has advantages for innovative companies, owners may try first to obtain debt financing. The interest payable for bank loans is much lower than the required returns of venture capitalists or other equity providers, and owners lose less control when taking out bank loans.

Second, we also expect an influence of self-selection. Many owners of innovative companies will anticipate possible problems with access to bank financing. They will only engage in 
innovative activities if access to alternative financing sources, such as equity capital or internally generated cash flow, seems likely. For example, it is found for German SMEs that a sufficiently high equity ratio positively affects the decision to conduct $R \& D$ activities, especially for young companies (Mueller and Zimmermann, 2008). The results of the study by Bond et al. (2006) can also be interpreted in the light of self-selection. The cash flow of British companies determines whether $R \& D$ is carried out but does not influence the level of R\&D activity. Thus, sufficient cash flow is a precondition for R\&D. The authors find that R\&D performers are a self-selected group that faces fewer financial constraints than do companies without R\&D.

Third, owners of innovative companies may have not been aware of the suitability of equity financing. Banks may inform owners about the advantages of this form of financing when explaining the reasons for their denial.

It is possible to derive two testable hypotheses to investigate our conjecture that innovative companies are better able to cope with loan denials. The first hypothesis relates to the investment performance of companies. We hypothesize that innovative companies are able to realize a higher share of their planned investment than non-innovative companies when facing a loan denial. The second hypothesis predicts how companies ultimately finance their investment. We hypothesize that innovative companies finance a larger share of their investment with external equity than non-innovative companies when confronted with a loan denial. It is expected that innovative companies are able, to a certain degree, to substitute external equity for unavailable debt.

\section{Methodology}

We use a Tobit model with a correction for selection as our preferred econometric model (see Wooldridge, 2002, p. 575ff.). Our dependent variable is the share of actual to planned investment. It has mass points at both zero and 100, which the Tobit model can account for. Loan denials are not random events, but are influenced by observed factors such as the equity ratio as well as private information that the banks possess either through their long-term relationship with the customer or through the assessment of the loan application. The main aspects of the private information of banks are the expected profitability of the company and the expected profitability of the investment project. This information is unobservable for us but may influence both the loan decision and the investment behavior. Neglecting its influence may result in selection effects that bias the estimates of the investment equation. $\mathrm{Li}$ 
and Prabhala (2006) give a detailed account of the use of selection models in corporate finance.

Hence our econometric model is an extension of the classical Heckman selection model (Heckman, 1976), consisting of the following equations:

$$
y_{i}^{*}=d_{i} \beta_{d}+I_{i} \beta_{I}+d_{i} I_{i} \beta_{d I}+x_{i}^{\prime} \beta+\varepsilon_{i} \quad \text { (main equation) }
$$

$$
d_{i}^{*}=z_{i}^{\prime} \delta+u_{i} \text { (selection equation) }
$$

$y_{i}^{*}$ represents the latent variable for investment performance (share of actual to planned investment) for which the following observation rule applies:

$$
\begin{aligned}
& y_{i}=y_{i}^{*} \text { if } 0<y_{i}^{*}<100 \\
& y_{i}=0 \text { if } y_{i}^{*} \leq 0 \\
& y_{i}=100 \text { if } y_{i}^{*} \geq 100
\end{aligned}
$$

For the latent variable $d_{i}^{*}$ capturing loan denial a binary observation rule with

$$
\begin{aligned}
& d_{i}=1 \text { if } d_{i}^{*}>0 \\
& d_{i}=0 \text { otherwise }
\end{aligned}
$$

applies, where $d_{i}$ equals 1 if a loan denial is observed. The subscript $i$ indicates measurement of the variables at the company level. As can be seen from equation (1), the loan denial dummy is interacted with an innovation dummy $I$. We are therefore able to test whether the loan denial effect is different for innovative and non-innovative companies, which is the first main question of this paper. Furthermore, $x_{i}$ represents a vector of additional variables explaining the share invested and $z_{i}$ is a vector of variables explaining loan denials.

The error terms of the two equations are assumed to be jointly normally distributed with zero means, which yields the following variance-covariance matrix:

$$
\Sigma=\left(\begin{array}{l}
\sigma_{\varepsilon}^{2} \sigma_{u \varepsilon} \\
\sigma_{u \varepsilon} 1
\end{array}\right) .
$$

Due to the non-zero covariance $\sigma_{u \varepsilon}$ in this correlation structure, the potential endogeneity of loan denial in equation (1) has to be addressed within the econometric framework. The two equations can be either estimated with full simultaneous maximum likelihood or with a twostep procedure. We choose the two-step procedure for which it is necessary to include the 
inverse Mills ratio $\lambda_{i}=\frac{\phi\left(z_{i}^{\prime} \delta\right)}{\Phi\left(z_{i}^{\prime} \delta\right)}$ as an additional variable in the main equation, where $\phi$ denotes the standard normal density and $\Phi$ denotes the cumulative standard normal distribution. When calculating the standard errors of the Tobit model one has to take into account that $\lambda_{i}$ is estimated, which leads to a heteroscedastic $\varepsilon_{i}$. We therefore employ a bootstrapping procedure to obtain correct standard errors.

An exclusion restriction is necessary for the identification of the selection equation to not only rely on the functional form assumptions. For an exclusion restriction to be valid, the variable excluded from the main equation has to be related to the dependent variable of the selection equation but unrelated to the error term of the main equation. We use the intensity of banking competition as exclusion restriction. A higher density of bank subsidiaries in a district implies more competition. Banks may be more reluctant to deny loans because customers have more options to move their bank business to competitors. Because richer districts may attract more banks and companies in richer districts may be able to realize a higher share of their planned investment, we also control for the average income of households in the district. As additional controls at the district level we use dummies for the degree of urbanization. There may be differences in investment behavior in urban and rural areas and urban areas may attract more banks. Beyond the regional characteristics we control for, we believe that it is unlikely that the intensity of banking competition would have a direct influence on the share of planned investment that companies can realize. Although there is no formal test on the validity of an exclusion restriction, we performed a rough check by including the variable Banking competition in the main equation and found it to be insignificant.

Due to the non-linearity of our employed model, estimated coefficients do not correspond to marginal effects. We present marginal effects in the regression tables, because they show the economic significance of the results. We calculate average marginal effects, i.e. we change one regressor keeping the remaining regressors at their original values and then calculate the average of the thus obtained marginal effect over all observations. For dummy variables we evaluate changes from zero to one. ${ }^{2}$ The main variables of interest are the dummy for loan denial, the dummy capturing innovativeness and their interaction term. For the calculation of the two base effects of the interaction, we hold the respective other variable constant at zero, e.g., we calculate the marginal effect for loan denial holding innovativeness constant at zero and we calculate the marginal effect for innovativeness holding loan denial constant at zero.

\footnotetext{
${ }^{2}$ We use the Stata command "margins” for all calculations.
} 
The marginal effect of the interaction term is then calculated as the simultaneous change of loan denial and of innovativeness from zero to one. It is calculated as the double difference $\frac{\Delta^{2} y_{i}}{\Delta d_{i} \Delta I_{i}}$. With this calculation of the marginal effects we can obtain the total effect of loan denial and innovativeness by adding the marginal effects of the base terms and the interaction term.

\section{Data}

\subsection{Data Source}

The analysis is based on an annual survey of German SMEs, which has been conducted since 2003 by KfW Bankengruppe, Frankfurt/Main (KfW-Mittelstandspanel). The survey is representative for companies with maximum annual sales of 500 million Euro without a minimum requirement for the number of employees. It covers manufacturing, services, construction, retail and wholesale trade. The three waves with company information relating to the years 2005-2007 contain the necessary information for this study, namely the volume of planned and actual investment as well as detailed information on loan negotiations and innovative activity. The observation of planned investment and of the outcomes of loan negotiations is an important advantage of our data. For more detailed information on the data source see Reize and Lo (2008).

The sample of the survey is stratified according to six size classes (up to 4 employees, 5-9, 10-19, 20-49, 50-99, and 100 or more employees), five industries (manufacturing, construction, retail, wholesale, and services), two regions (Western and Eastern Germany), and participation in a government support program for SMEs conducted by KfW Bankengruppe. For the years 2005-2007 the survey achieved a response rate of between $18.2 \%$ and $23.4 \%$, which is in the typical range for company surveys.

From our research question it follows that we restrict the analysis to companies with planned or actual investment that also conducted loan negotiations. Figure A1 in the Appendix clarifies the selection procedure and presents the structure of the available information.

The three employed waves contain a total of 34,545 observations with information for 20,408 different companies. The restriction to companies with planned or actual investments leads to 24,256 observations (15,941 companies). Further restricting the sample to companies with demand for bank loans results in 10,438 observations (8,021 companies). The elimination of implausible values leaves us with 7,333 observations (5,668 companies). Specifically, we 
omit companies with return on sales of larger than $101 \%$ or smaller than $-101 \%$, with an equity ratio of smaller than $-110 \%$, and with inconsistent balance sheet information. With the further restriction to observations with non-missing entries in the regression variables we arrive at the final data set used for the analysis with 4,587 observations (3,543 companies) for the differentiation according to innovator/non-innovator and with 4,582 observations $(3,548$ companies) for the differentiation according to R\&D activity.

The survey is conducted as a panel, but the time dimension of our data is very limited. On average we have only 1.3 observations per company. On the one hand this is due to companies not responding in specific years; on the other hand, especially small companies do not plan to invest every year and do not have demand for additional bank financing every year. We rely on the cross-sectional information of the data and do not use panel estimators, since we would otherwise lose too many observations. Specifically, 58\% of the companies are observed only once. All standard errors are clustered at the company level and are robust to heteroscedasticity.

\subsection{Endogenous and Exogenous Variables}

The dependent variable of our analysis is Share invested. It is defined as the amount of actual investment divided by the amount of planned investment in a specific year. The variable is bounded between zero and 100. In a first step respondents are asked for the volume of actual fixed investment. Next they are asked which amount of the planned fixed investment they could not realize. Share invested is therefore calculated as follows:

$$
\text { Share invested }=\frac{\text { actual investment }}{\text { planned but not realized investment }+ \text { actual investment }}
$$

Fixed investment includes, for example, investments in buildings, machinery, office equipment, and acquisitions of other companies. The survey does not cover cases in which more investment than planned has been realized. It is important to note that the survey question does not restrict to investment that could not be realized due to unavailability of finance. The amount not realized contains also cases of technological infeasibility or cases where at a later stage of the planning process it was found that a project was not profitable after all.

The survey provides information on whether all, some, or none of the loan negotiations of a given year were successful. If only some or no negotiations were successful, it is reported whether the company did receive a loan offer from the bank for at least one ultimately failed 
negotiation. If this is the case we can conclude that the company declined at least one offer itself. From this information we build two variables capturing loan denial. For our basic results we use the variable Loan denial $A$. It is equal to one if a company for which none or only some negotiations were successful did not receive an offer from a bank for at least one ultimately failed application. It is zero if a company was always successful with negotiations or declined at least one offer itself. The idea behind this grouping is that companies that decline an offer are less credit-constrained than companies that do not receive an offer at all. The average value of Share invested is $94.8 \%$ for companies that were always successful with their loan negotiations, $81.9 \%$ for companies that declined at least one offer by a bank, and $54.3 \%$ for companies that did not receive an offer from their bank at least once for an ultimately failed negotiation. The mean values of actual investment volume are 1.2 million Euro, 1.0 million Euro, and 0.4 million Euro, respectively. Thus, if a company declines a loan offer in our sample this has to be interpreted in the sense that this company is not really dependent on the money from the one bank but has access to alternative sources of financing. ${ }^{3}$ Declining an offer is typically not the outcome of a situation in which banks make very unfavorable offers in the anticipation that the companies will not take them up.

As a robustness check we use the variable Loan denial B, which is equal to one if a company was never successful with loan negations and, additionally, did never receive an offer from a bank. This is a very strict definition of loan denial. In contrast to Loan denial A it does not include companies which were successful with some negotiations. Figure A1 in the Appendix also includes a diagrammatic depiction of the definitions of the loan denial variables.

The loan applications in our sample refer to spot loans and not to lines of credit. A line of credit gives the company the right to borrow up to a specified amount over a certain period for a price that is specified in advance (Martin and Santomero, 1997). Lines of credit are an important form of bank commercial lending in the US. For SMEs in the US, 52\% of lending from financial institutions takes the form of lines of credit, the rest being composed of spot loans. Lines of credit are normally used to finance working capital, whereas large investments are funded with spot loans (Berger and Udell, 1998). Lines of credit are not common in Germany where most commercial lending is arranged via spot lending contracts. Companies start negotiations with banks at the time they experience the credit need. Analysis of our data shows that only $4 \%$ of the investment volume is financed via an overdraft facility.

\footnotetext{
${ }^{3}$ Companies without loan negotiations realize on average an investment volume of 0.4 million Euros, the same volume as companies that did not receive an offer from their bank at least once. Internal sources of finance are presumably sufficient for smaller investment volumes.
} 
Two different concepts are used to differentiate between innovative and non-innovative companies. First, the dummy Innovator is equal to one if a company introduced a new product or a new process in the three years preceding the survey, and zero otherwise. Second, the dummy Continuous $R \& D$ is equal to one if the company performs $R \& D$ continuously, i.e. has positive $R \& D$ expenditures in each of the past years; the dummy Occasional $R \& D$ is equal to one if the company performs $R \& D$ only occasionally, which means that the company had positive $R \& D$ expenditures in some years in the past, but not in all. The reference category is companies without R\&D activities. Innovation is measured at the company and not at the project level in both cases. A separate analysis of the data source used for this study reveals that the reasons for loan denials are mostly grounded in company characteristics and not in project characteristics (Reize, 2007). Banks cite insufficient collateral as reason in 73\% of denials, insufficient creditworthiness in $41 \%$ of denials, and an unprofitable investment project in only $8 \%$ of denials (multiple answers were possible).

We include several control variables for company characteristics. The control for company size is the number of employees at full-time equivalents and its square (Employees and Employees squared). Company age is covered as years since founding and its square (Age and Age squared). Return on sales is calculated as the amount of profits after taxes divided by the amount of sales. Equity ratio is defined as equity divided by total assets. Capital intensity is measured as tangible assets divided by total assets. The variable Capital intensity proxies for the ability of the company to provide collateral. Furthermore, we include a dummy variable Limited liability, which is equal to one if the legal form of the company is characterized by limited liability. The variable West Germany is equal to one if the company is located in the western part of Germany. If a company has participated in a government support program conducted by KfW Bankengruppe, the variable Support program is equal to one. We also include year dummies and industry dummies measured at the 2-digit SIC level. Our controls include all variables that were used for the stratification of the sample.

As exclusion restriction for the selection equation we use Banking competition. This variable is defined at the district level as the number of bank subsidiaries active in a district divided by the population measured in 10,000 of the district. ${ }^{4}$ Data on the number of subsidiaries at the district level were obtained from the Bundesbank, the German central bank. The variable is

\footnotetext{
${ }^{4}$ Germany is divided into 439 districts (Kreis or kreisfreie Stadt). Berlin is the largest district with a population of 3.4 million and Zweibrücken is the smallest district with a population of 36,000 (in the year 2000). Since districts vary greatly with respect to size and more bank subsidiaries will be active in larger districts, we use the population as normalization.
} 
time-invariant and measured for the year 2000. Unfortunately, this statistic is not available for later years. The majority of subsidiaries is from cooperative banks (Volks- und Raiffeisenbanken), from savings banks (Sparkassen), and from private banks (e.g. Deutsche Bank). We exclude building associations, investment trusts, and subsidiaries from foreign banks that act as pure correspondence banks, because they do not extend loans to companies. At the district level we also control for the average income per resident in 1,000 Euro in the year 2000 (Income district level). We include dummies to differentiate among the district types rural district, urban district, and metropolitan area. The district type data relate to the year $2002 .^{5}$ Since the employed district characteristics are quite time consistent, we choose to measure them for one year only.

\subsection{Descriptive statistics}

Table 1 contains the descriptive statistics for the variables used in the analysis. The variable Share invested shows a high degree of variation. Its minimum at zero is due to companies which planned to invest but were unable to invest at all in a given year. Its maximum at 100 covers companies that are able to realize the full amount of planned investments. On average, companies can realize $87.5 \%$ of their planned investments. $13 \%$ of the companies experience a loan denial according to our basic definition of Loan denial A. According to the narrower definition of Loan denial B the share is 7.5\%.

Sixty-four percent of the companies are classified as innovators. The share of companies with R\&D activities is substantially smaller; $17.3 \%$ perform R\&D activities continuously and $14.0 \%$ perform R\&D occasionally. The average number of employees is 69 , as could be expected for a survey of SMEs. On average, companies have return on sales of $3.8 \%$, an equity ratio of $18.0 \%$, and a capital intensity of $37.1 \%$. $65.1 \%$ of the companies participate in a government support program, which means that they are overrepresented in this survey.

The exclusion restriction Banking competition has an average value of 5.4, indicating that 5.4 bank subsidiaries serve on average a population of 10,000.

\footnotetext{
${ }^{5}$ Income per capita and population figures are taken from Statistic regional 2004, German National Statistical Offices (Statistische Ämter des Bundes und der Länder). The categorization of district types follows INKAR 2004, Federal Office for Construction and Regional Planning (Bundesamt für Bauwesen und Raumordnung).
} 


\section{Empirical Analysis}

\subsection{Access to Bank Loans and Realization of Investment Plans}

Table 2, columns 1 and 2, presents the two steps of the Tobit model with selection correction. It shows results for our basic measure of loan denial, Loan denial A, and for the classification of companies into innovators and non-innovators. The selection equation in column 1 is a probit regression with the dummy for a loan denial as dependent variable. Our exclusion restriction Banking competition is significant at the $1 \%$ level. Its negative sign indicates that a higher degree of competition is related to a smaller probability of a loan denial. With higher competition banks may be more reluctant to deny loan applications, because customers have more opportunities to move their business to competitors should they be unsuccessful with their loan request. As is expected from theory, innovators have a higher probability of experiencing a loan denial because they have a more dispersed return distribution. The other company characteristics also confirm expectations. Higher values of Return on sales, Equity ratio, and Capital intensity each decrease the probability of a loan denial. Larger companies, older companies, and companies with limited liability have smaller denial probabilities. The further controls for district level characteristics do not turn out to be significant (variables not shown in the table).

Column 2 includes the investment equation with selection correction, which has Share invested as dependent variable. The dummy Loan denial $A$ has, as expected, the largest influence. The share of realized investment decreases by 68.1 percentage points when a noninnovator faces a loan denial. The size of the marginal effect has to be interpreted in comparison with the basis category of a non-innovator with no denial. The results further show that innovators without a denial realize a 1.8 percentage point smaller value of Share invested than non-innovators without a denial. This can be explained by the higher technological and demand uncertainty faced by innovators. As companies obtain more information over time, they realize that some envisaged projects are unprofitable after all and should be cancelled.

Of most interest to our research question is the positive and significant marginal effect on the interaction term of Loan denial A and Innovator. This implies that having the attribute of Innovator the negative effect of loan denial is 11.8 percentage points lower than for noninnovators. ${ }^{6}$ The results also show that the positive effect of interaction between Loan denial

\footnotetext{
${ }^{6}$ It also implies that having the attribute of Loan denial A innovators are able to realize additional 11.8 percentage points of Share invested compared to non-innovators.
} 
$A$ and Innovator even outweighs the negative innovation effect. Innovators with denials are able to invest 10.0 percentage points more than can non-innovators with denials. ${ }^{7}$ Thus, innovators are better able to cope with loan a denial, which confirms our first hypothesis. The projects of innovative companies are likely to be risky but may generate high expected returns. Even if banks deny a loan because of the high risk, companies may still be able to find alternative financing sources if the returns are attractive. Banks are sometimes not able to judge the prospects of very innovative companies, because specialized technical and marketoriented knowledge would be necessary to do so. It can be rational for banks not to invest in this knowledge and to forgo the possibility of providing finance to this type of company.

Of the company control variables only Return on sales and Support program are significant. Return on sales has probably a persistent component and is therefore partly forward looking. It can be expected that profitable companies are again profitable in the future and are thus more likely to realize their investment projects. ${ }^{8}$ The insignificant regressors Equity ratio and Capital intensity reflect the resources available inside the company. Our results should not be interpreted to mean that these variables are not important for the investment performance. Both variables play an indirect role by improving the access to bank loans as shown in the first step. The large effect of loan denial on Share invested in the second step shows that this access is the most important factor influencing the share of realized investment.

The variable Inverse Mills ratio corrects for selectivity. Its positive sign means that unobserved company characteristics have a positive influence both on Loan denial A and on Share invested. The variable Rho gives the correlation between the error terms of the first and the second step regressions. The value of 0.46 is evidence for a relatively high positive correlation. This is an indication that unobserved factors indeed influence both the credit decision by the bank and the capacity of the company to realize investment plans.

It is instructive to compare the results of the investment equation with and without selection correction (column 2 and column 3) to get an impression of the influence of selectivity. Column 3 without selection correction shows higher marginal effects and higher significance levels for some company characteristics. The variables Return on sales, Equity ratio and Employees proxy partly for unobserved company characteristics, such as the quality of the

\footnotetext{
${ }^{7}$ This value is calculated as the sum of the marginal effects of Innovator and the interaction term.

${ }^{8}$ The financial constraints literature uses cash flow related variables, such as return on sales, in order to identify financial restrictions (see e.g. Bond et al., 2006 or Engel and Middendorf, 2009). We are able to directly control for financial constraints with our loan denial variables. In our model return on sales has the more direct interpretation of profitability.
} 
management and stability. Once these unobservables are controlled for by the selection equation, these variables have a diminished role. In contrast, the influence of the loan denial itself is higher when selection is controlled for.

Columns 4 to 6 of Table 2 display regression results when using R\&D activity to classify companies into innovative and non-innovative. The selection equation in column 4 shows again a significant influence of Banking competition. Furthermore, companies with either occasional or continuous R\&D face a higher probability of a loan denial. The size of the effect of $\mathrm{R} \& \mathrm{D}$ is almost double the size of the effect of being an innovator in the analogous specification of column 1 . Thus performing $R \& D$ is a larger obstacle for obtaining bank finance than introducing a new product or a new process. A major difference between the two classifications for innovativeness is that conducting $R \& D$ takes place at an earlier stage of the innovation process than the introduction of new products or processes. Conducting R\&D is a pure input factor. When conducting $R \& D$ it is not clear that the activity will result in a marketable product. In contrast, innovators have already been successful with the introduction of a new product or process. Performing R\&D implies therefore a higher level of risk.

Column 5 displays the investment equation with selection correction. As before, the dummy for loan denial has quantitatively the largest influence on Share invested. Companies without R\&D facing a denial have to cut down the share of realized investment by 60.4 percentage points compared with the reference category of companies without R\&D and with successful loan negotiations. Reflecting uncertainty, the dummies for occasional and continuous R\&D are negative. The dummy for continuous $R \& D$ is smaller in absolute value, suggesting that companies with continuous $R \& D$ have to cut back less, possibly because they have more experience with the planning of risky projects.

The interaction term for occasional $R \& D$ and loan denial is insignificant. Thus, companies with occasional $R \& D$ have no better investment performance than companies without $R \& D$ when facing a loan denial. Conducting only occasional R\&D may make companies not attractive enough for equity investors seeking high risk-high return investments. We can therefore not confirm Hypothesis 1 for this company type. In contrast, the interaction term for companies with continuous $R \& D$ is positive and significant. Companies with continuous R\&D may be more attractive for equity investors and may have been more active in exploring alternatives to a bank loan from the beginning than have companies with only occasional R\&D. Companies facing a loan denial and conducting continuous $R \& D$ are able to invest 9.9 percentage points more of Share invested than companies facing a loan denial without R\&D 
activity. Again, this value is calculated as the sum of the marginal effect of continuous $R \& D$ (-2.2 percentage points) and the marginal effect of the interaction term (12.1 percentage points). The loss through uncertainty at the planning stage is more than compensated for through better performance after a loan denial for companies with continuous R\&D. Our results are therefore consistent with Hypothesis 1. We can conclude that companies with continuous R\&D activity are better able to cope with loan denials. The influence of the other control variables is very similar to the analogous specification of the second step for the innovator characteristic (column 2).

\subsection{Robustness Checks}

In Table 3 we present robustness checks with the more stringent definition of loan denial, Loan denial B, which confirm our key findings. The exclusion restriction Banking competition is again significant in the first steps. A loan denial is still quantitatively the most important influence on the share of planned investment that can be realized. Furthermore, being an innovator has a negative effect on Share invested. The interaction term between being an innovator and loan denial is positive and significant and outweighs the negative base effect of innovation. Hence, our result that innovators can better cope with loan denials than non-innovators is confirmed. The investment patterns for companies with occasional and continuous R\&D are also confirmed with the alternative loan denial measure. As before, only companies with continuous $R \& D$ are better able to cope with loan denials. Companies with occasional R\&D show no better performance than companies without R\&D when facing a denial.

Interestingly, the Inverse Mills ratio is now insignificant for both measures of innovation and the correlation coefficient Rho is close to zero. This indicates that selection on unobservables is of minor importance for Loan denial $B$. The marginal effects and significance levels of the regressors of the investment equation with and without control for selectivity are consequently very similar. Hence, estimating a two step procedure is not necessary for this specification from an econometric point of view. Specifically, a comparison of the results of columns 3 and 4 as well as columns 5 and 6 shows that the marginal effect of Loan denial $B$ is very similar for the one-step and two-step procedure. The same holds true for the interaction term. $^{9}$

\footnotetext{
${ }^{9}$ As further exploration we checked the robustness of the results with loan denial variables that do not condition on the company not receiving an offer from a bank at least once (results not shown), i.e. a denial also takes place if the company declines at least one offer itself. The analogue to Loan denial A is equal to one if a company was
} 


\subsection{Financing Mix for Actual Investment}

Tables 4 and 5 show how companies ultimately finance their actual investment. We are able to differentiate between external equity, mezzanine capital, bank loans, internal funds, public funds and other sources. Companies are classified into four groups according to innovative and non-innovative, and experiencing and not experiencing loan denials. From the tables it can be seen whether innovative companies move into different forms of financing when confronted with a loan denial.

Table 4 presents the results of our basic, less stringent, measure of access to bank loans, Loan denial $A$, which also includes companies that were sometimes successful with loan applications. Our second hypothesis predicts that innovative companies facing loan denials use external equity more heavily. External equity financing includes equity investments and investments with equity characteristics of new owners, including venture capital and business angel financing. Innovators with a loan denial finance $6.7 \%$ of their investment with external equity whereas innovators without problems in access to bank loans use this form of financing only for $1.1 \%$ of total investment. The shares for companies with R\&D activity are $9.2 \%$ and $0.7 \%$, respectively. ${ }^{10}$ We thus find a quantitatively important move towards external equity financing for innovative companies experiencing loan denials, which confirms our second hypothesis. This result can partly explain why innovative companies are able to realize a higher share of their planned investment than non-innovative companies, when facing a loan denial. To get a better understanding of this result, we compare the $R \& D$ intensity (R\&D expenditure/sales) of innovative companies with and without loan denials and find that the ones with loan denials have on average a higher $R \& D$ intensity. They constitute therefore the subgroup of innovative companies that are more attractive for alternative sources of financing, such as venture capital. This result is found for both measures of innovativeness.

Our results are consistent with the findings of Gatchev et al. (2009) for listed companies in the US. The authors investigate, among else, which financing sources companies use for different types of investments. Expenses for R\&D and advertising are predominantly financed

\footnotetext{
successful with none or some negotiations irrespective of whether it received an offer from the bank or not. We find that innovative companies can invest significantly more when facing a loan denial, but a value of Rho larger than one indicates problems with the specification. As analogue to Loan denial B we explored the robustness of the results for a loan denial variable which is equal to one if a company was never successful with loan negotiations irrespective of whether it received an offer from the bank or not. Again, we find that innovative companies can invest significantly more when facing a loan denial. Finding similar results for the four loan denial measures that can be built from our data makes us confident in the robustness of the results.

${ }^{10}$ For this part of the analysis we combine companies with continuous and occasional R\&D into one group to achieve a higher number of observations.
} 
by equity issues, whereas investment in net fixed assets are financed with long-term debt issues and equity issues with equal shares. Equity is therefore used for investments with a high degree of information asymmetry.

For mezzanine capital (e.g., subordinated loans, profit participation rights, silent partnerships) we also see an increased use by innovative companies facing a loan denial, but the increase is smaller than that for external equity. Having characteristics of both debt and equity, this financing form is also well suited for innovative companies. For example, the junior tranche of subordinated loans does not require collateral and no fixed interest payment is required for profit participation rights. Overall, mezzanine capital is more heavily used by innovative than by non-innovative companies, though the absolute importance of this financing form is limited.

Bank loans are the most important type of financing for all subgroups. ${ }^{11}$ For innovative companies this financing type is about 10 percentage points less important than for noninnovative companies, which conforms to theoretical expectations. We find that for investment projects of German SMEs bank loans are a more important form of external funding than new equity. This is in contrast to the result by Gatchev et al. (2009) for listed companies, which shows that additional fixed assets are financed to equal parts by new debt and new equity. The higher reliance on bank loans by SMEs can be explained by the lack of access to public equity markets.

The share of bank financing for companies facing a denial may seem rather high. This is due to the fact that the group of companies facing at least one denial is a group with possibly more than one loan negotiation, of which some could be successful. Even though they experience problems, companies may still be able to use bank financing. Especially companies using bank finance heavily are likely to negotiate several loans and have therefore a higher probability that at least one negotiation is unsuccessful. This can explain why for noninnovative companies with a denial the share of bank financing even shows a slight increase. It is also important to note that only companies with positive actual investment can be included in this part of the analysis. Of the companies facing a loan denial $18.2 \%$ had to cancel their investment plans completely and are therefore not included. This exclusion leads

\footnotetext{
${ }^{11}$ This result is due to the fact that only companies conducting loan negotiations are examined within this analysis. For all SMEs internal funds are the most important type of financing with a share of $43 \%$ in 2006 , whereas bank loans are used to finance $31 \%$ of investments (Reize, 2007).
} 
to a bias towards companies with access to some form of finance, even if they experienced some problems.

Innovative companies without a denial use a higher share of internal funds (e.g., current and accumulated past profits) than do innovative companies facing a denial. A strong internal contribution to the investment project is probably a precondition for banks to extend loans to innovative companies, since internal funds act as a risk buffer. There are no differences with respect to the use of internal funds for non-innovative companies with or without a loan denial.

Public funds are comprised of bank loans with subsidized interest rates, for which the state takes on part of the default risk and of equity capital provided through government agencies. We find that companies with denials use a smaller share of public funds, because our definition of loan denials partly includes unsuccessful applications for public funds.

Table 5 shows the robustness check for our alternative measure of access to bank loans, Loan denial $B$. This more stringent measure includes companies only in the 'denied' category, if they were never successful with their applications. In the robustness check we find an even more profound increase in the use of external equity for innovative companies with denied loan applications. Differences in the financing shares have to be interpreted in the light of the more stringent denial measure. Companies with no successful loan application are under more pressure to access alternative sources of financing. This robustness check also provides support for our second hypothesis. ${ }^{12}$ In contrast to our basic measure of loan denial, we find no increase in the use of mezzanine capital for innovative companies facing a denial.

With the more stringent loan denial measure we observe a larger drop in bank loans for unsuccessful companies as would be expected. The share of bank financing does not drop to zero because bank financing also includes the use of overdraft facilities. For companies facing a denial, around $80 \%$ of the bank loans are represented by the use of an overdraft facility, for which in general no separate negotiation takes place. $^{13}$

It is important to note that companies worst hit by loan denials are the ones completely precluded from investing. These companies are excluded from the financing mix results,

\footnotetext{
${ }^{12}$ As for the regression results, we also checked the robustness of the results for the analogues of Loan denial A and Loan denial $B$ defining a denial also to have taken place if the company declines an offer from a bank. For both alternative definitions we see a strong increase in the use of external equity for innovative companies facing a denial but not for non-innovative companies facing a denial. Thus, the second hypothesis is also confirmed for the analogous measures.

${ }^{13} \mathrm{~A}$ differentiation between overdrafts and other bank loans is only possible for the year 2006.
} 
because they have no investment to finance. This consideration explains why we observe an increased use of internal funds for denied companies, whether innovative or not, when using the Loan denial $B$ measure. Only denied companies which can fall back on alternative financing sources are able to invest if all negotiations with banks fail. Denied non-innovative companies mainly fall back on internal funds whereas denied innovative companies are able to access external equity. Interestingly, for the less stringent measure, Loan denial A, we find a smaller share of internal funds for innovative companies facing a denial instead of a larger share for Loan denial B. For the less stringent measure it is not the effect of substitution into different forms of financing that dominates, but the requirement of having a strong equity base in order to access bank loans.

\section{Conclusions}

In this study we investigate how loan denials influence the investment and financing behavior of companies. We find that innovative companies are better able to deal with loan denials. Specifically, innovators are able to realize 10.0 percentage points more of the share of actual to planned investment than non-innovative companies. Innovative companies are able to rely more on the alternative financing source of external equity, when confronted with a loan denial. It has to be remarked, however, that even though innovative companies can better cope with loan denials, a loan denial nevertheless implies a substantial reduction in the investment volume in absolute terms.

Our study has implications for economic policy and for managers of companies. For policy makers it is not only important to know which types of companies have access to bank loans, but also to know how investment is affected if no access is available. From the shift of innovative companies into equity it can be learned that not only sufficient provision of funds through banks is important but that equity markets have to work as well. This allows companies to choose the form of financing that is best suited for them. From a management perspective, our results stress the importance of anticipating the possibility of a loan denial and to take equity-based financing alternatives early into consideration. However, it should also be noted that venture capital as a specific form of external equity is suitable for only a small share of SMEs in Germany. Reize and Zimmermann (2009) show that in particular companies with a high $R \& D$ intensity or with continuous $R \& D$ activity are financing a relative high share of their innovation expenditures with venture capital. 
One limitation of our study is the need to restrict the analysis to companies that planned to invest and also planned to use bank loans for the financing of the investment. This selection excludes companies that are from the start discouraged from filing a loan application because they expect a denial anyway. It also excludes companies with a very high level of innovative activity that try venture capital financing as their first option. Furthermore, we also exclude companies that have small investment volumes for which internal funding is sufficient and companies which have sufficient internal funding even for large investment projects. However, our results are relevant for SMEs with high economic importance. Of the $58 \%$ of German SMEs which invested or planned to invest in the year 2007, 36\% had a need for external financing for their investment. Our sample selection criteria thus cover $21 \%$ of German SMEs. These companies are responsible for $29 \%$ of the employment in German SMEs. Considering that many companies invest and try to access external funding not every year, our results are relevant for companies with an even higher share of economic activity. ${ }^{14}$

In future research it would be worthwhile to extend this work in two directions. First, it would be interesting to investigate the long-term consequences of loan denials for the performance and survival of companies. Second, it would be interesting to investigate the consequences of problems with access to other forms of external financing in addition to bank loans.

\footnotetext{
${ }^{14}$ Restricted to the observations in our sample and thus not representative for the overall economy, we find that in the year 2007 30\% of the companies planned to invest and tried to access bank loans. When we extend the time period for these activities to happen at least once to the three years of 2005-20007, this share increases to $41 \%$ of companies.
} 


\section{Tables and Figures}

Table 1: Descriptive Statistics

\begin{tabular}{|l|c|c|c|c|c|}
\hline Variable & Mean & Median & Std. dev & Min & Max \\
\hline Share invested (in \%) & 87.54 & 100 & 26.63 & 0 & 100 \\
\hline Loan denial A & 0.130 & 0 & 0.337 & 0 & 1 \\
\hline Loan denial B & 0.075 & 0 & 0.263 & 0 & 1 \\
\hline Innovator & 0.639 & 1 & 0.480 & 0 & 1 \\
\hline Occasional R\&D & 0.140 & 0 & 0.347 & 0 & 1 \\
\hline Continuous R\&D & 0.173 & 0 & 0.379 & 0 & 1 \\
\hline Employees & 69.34 & 34 & 135.2 & 0.5 & 3550 \\
\hline Age (in years) & 38.12 & 18 & 40.84 & 2 & 414 \\
\hline Return on sales (in \%) & 3.805 & 2.44 & 9.130 & -100 & 91.62 \\
\hline Equity ratio (in \%) & 17.95 & 15.95 & 21.71 & -103.33 & 100 \\
\hline Capital intensity (in \%) & 37.05 & 33.53 & 25.49 & 0 & 108.59 \\
\hline Limited liability & 0.768 & 1 & 0.422 & 0 & 1 \\
\hline West Germany & 0.610 & 1 & 0.488 & 0 & 1 \\
\hline Support program & 0.651 & 1 & 0.477 & 0 & 1 \\
\hline Banking competition & 5.402 & 4.66 & 2.325 & 2.28 & 17.58 \\
\hline
\end{tabular}

Note: The descriptive statistics are not weighted by survey weights. They reflect the distribution in the survey. 
Table 2: Basic Results for Investment Performance (Loan Denial A)

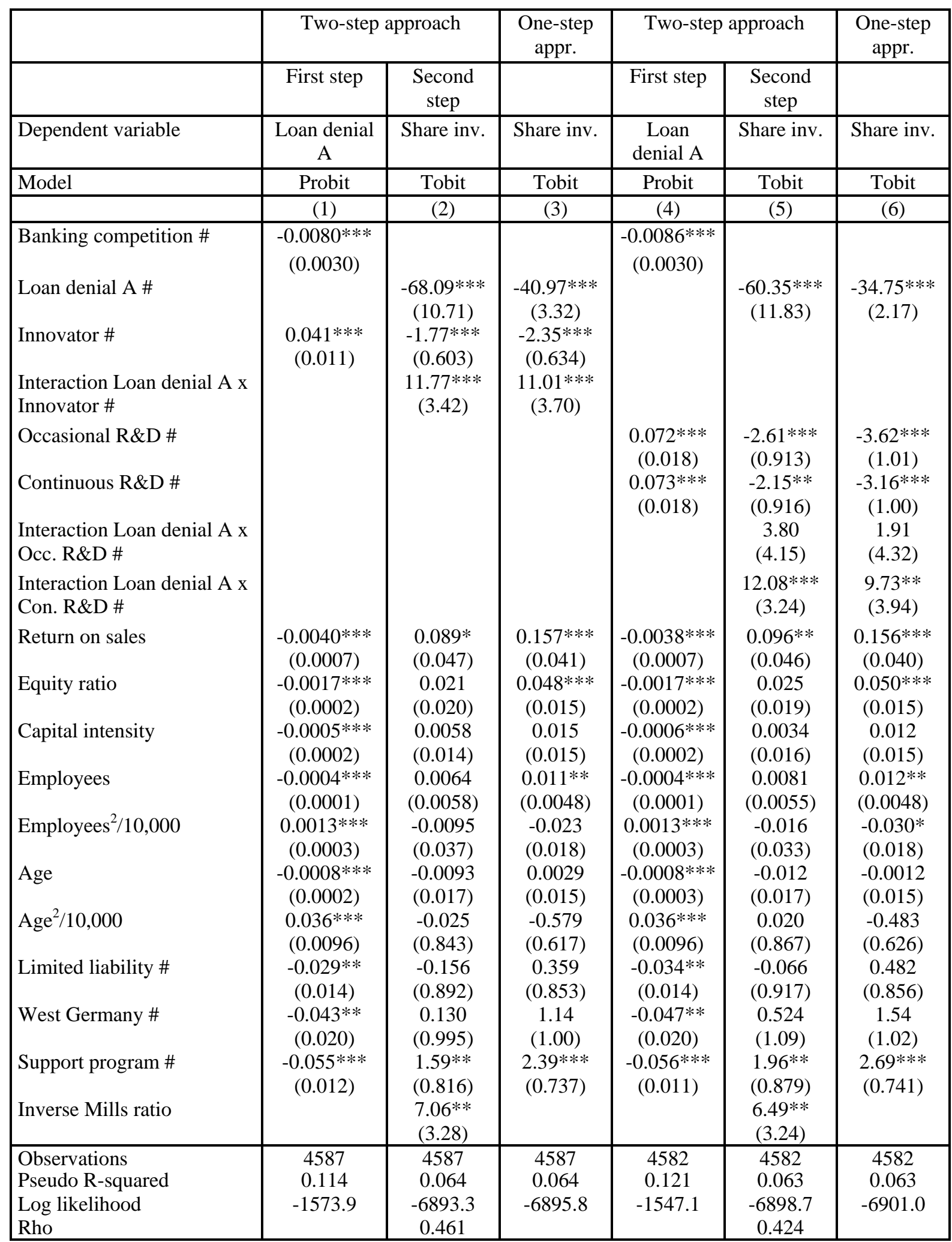

Note: Average marginal effects and their standard errors are shown. Marginal effects for the dummy variables (denoted with \#) are calculated for a change from zero to one. The marginal effects of the interaction terms take the simultaneous change of both dummy variables from zero to one into account. All estimates contain the income at district level, dummies for district type, industry dummies at the 2-digit SIC level and year dummies. Standard errors are robust to within company correlation and to heteroscedasticity. Standard errors for columns 2 and 5 are estimated with bootstrapping with 400 replications. ***, **, and * indicate statistical significance at the $1 \%, 5 \%$, and $10 \%$ levels, respectively. 
Table 3: Robustness Check for Investment Performance (Loan Denial B)

\begin{tabular}{|c|c|c|c|c|c|c|}
\hline & \multicolumn{2}{|c|}{ Two-step approach } & \multirow{2}{*}{$\begin{array}{c}\text { One-step } \\
\text { appr. }\end{array}$} & \multicolumn{2}{|c|}{ Two-step approach } & \multirow{2}{*}{$\begin{array}{c}\text { One-step } \\
\text { appr. }\end{array}$} \\
\hline & First step & $\begin{array}{l}\text { Second } \\
\text { step }\end{array}$ & & First step & $\begin{array}{l}\text { Second } \\
\text { step }\end{array}$ & \\
\hline Dependent variable & $\begin{array}{c}\text { Loan denial } \\
\text { B }\end{array}$ & Share inv. & Share inv. & $\begin{array}{c}\text { Loan } \\
\text { denial B }\end{array}$ & Share inv. & Share inv. \\
\hline Model & Probit & Tobit & Tobit & Probit & Tobit & Tobit \\
\hline & $(1)$ & $(2)$ & $(3)$ & $(4)$ & $(5)$ & $(6)$ \\
\hline Banking competition \# & $\begin{array}{c}-0.0053^{* *} \\
(0.0023)\end{array}$ & & & $\begin{array}{c}-0.0055^{* *} \\
(0.0023)\end{array}$ & & \\
\hline Loan denial B \# & & $\begin{array}{c}-44.76^{* * *} \\
(14.58)\end{array}$ & $\begin{array}{c}-46.76^{* * *} \\
(4.27)\end{array}$ & & $\begin{array}{c}-41.66 * * * \\
(12.41)\end{array}$ & $\begin{array}{l}-40.49 * * * \\
(2.91)\end{array}$ \\
\hline $\begin{array}{l}\text { Innovator \# } \\
\text { Interaction Loan denial B x } \\
\text { Innovator \# }\end{array}$ & $\begin{array}{c}0.012 \\
(0.0083)\end{array}$ & $\begin{array}{c}-3.07 * * * \\
(0.697) \\
11.01 * * \\
(4.67)\end{array}$ & $\begin{array}{c}-3.04 * * * \\
(0.679) \\
11.03 * * \\
(4.93)\end{array}$ & & & \\
\hline Occasional R\&D \# & & & & $\begin{array}{l}0.029 * * \\
(0.014)\end{array}$ & $\begin{array}{c}-4.29 * * * \\
(1.15)\end{array}$ & $\begin{array}{c}-4.32 * * * \\
(1.08)\end{array}$ \\
\hline $\begin{array}{l}\text { Continuous R\&D \# } \\
\text { Interaction Loan denial B x } \\
\text { Occ. R\&D \# }\end{array}$ & & & & $\begin{array}{c}0.029 * * \\
(0.014)\end{array}$ & $\begin{array}{c}-4.15 * * * \\
(1.14) \\
-5.37 \\
(5.92)\end{array}$ & $\begin{array}{c}-4.18 * * * \\
(1.08) \\
-5.39 \\
(5.79)\end{array}$ \\
\hline $\begin{array}{l}\text { Interaction Loan denial B x } \\
\text { Con. R\&D \# }\end{array}$ & & & & & $\begin{array}{l}15.80 * * * \\
(6.01)\end{array}$ & $\begin{array}{l}15.67 * * * \\
(5.56)\end{array}$ \\
\hline Return on sales & $\begin{array}{c}-0.0030 * * * \\
(0.0005)\end{array}$ & $\begin{array}{l}0.166 * * * \\
(0.051)\end{array}$ & $\begin{array}{c}0.163 * * * \\
(0.044)\end{array}$ & $\begin{array}{c}-0.0029 * * * \\
(0.0005)\end{array}$ & $\begin{array}{c}0.163 * * * \\
(0.046)\end{array}$ & $\begin{array}{c}0.165^{* * *} \\
(0.043)\end{array}$ \\
\hline Equity ratio & $\begin{array}{c}-0.0010 * * * \\
(0.0003)\end{array}$ & $\begin{array}{c}0.068 * * * \\
(0.017)\end{array}$ & $\begin{array}{c}0.066 * * * \\
(0.016)\end{array}$ & $\begin{array}{c}-0.0010 * * * \\
(0.0002)\end{array}$ & $\begin{array}{c}0.067 * * * \\
(0.018)\end{array}$ & $\begin{array}{c}0.068 * * * \\
(0.016)\end{array}$ \\
\hline Capital intensity & $\begin{array}{c}-0.0005^{* * *} \\
(0.0002)\end{array}$ & $\begin{array}{c}0.018 \\
(0.014)\end{array}$ & $\begin{array}{c}0.017 \\
(0.015)\end{array}$ & $\begin{array}{c}-0.0005 * * * \\
(0.0002)\end{array}$ & $\begin{array}{c}0.015 \\
(0.015)\end{array}$ & $\begin{array}{c}0.015 \\
(0.015)\end{array}$ \\
\hline Employees & $\begin{array}{c}-0.0004 * * * \\
(0.0001)\end{array}$ & $\begin{array}{l}0.012 * * \\
(0.0059)\end{array}$ & $\begin{array}{l}0.012 * * * \\
(0.0048)\end{array}$ & $\begin{array}{c}-0.0004^{* * *} \\
(0.0001)\end{array}$ & $\begin{array}{l}0.014^{* *} \\
(0.0059)\end{array}$ & $\begin{array}{l}0.014 * * * \\
(0.0048)\end{array}$ \\
\hline Employees $^{2} / 10,000$ & $\begin{array}{c}0.0011^{* * *} \\
(0.0003)\end{array}$ & $\begin{array}{l}-0.029 \\
(0.037)\end{array}$ & $\begin{array}{l}-0.029 * \\
(0.018)\end{array}$ & $\begin{array}{c}0.0011^{* * *} \\
(0.0003)\end{array}$ & $\begin{array}{l}-0.036 \\
(0.035)\end{array}$ & $\begin{array}{c}-0.036 * * \\
(0.018)\end{array}$ \\
\hline Age & $\begin{array}{c}-0.0004^{* *} \\
(0.0002)\end{array}$ & $\begin{array}{c}0.014 \\
(0.020)\end{array}$ & $\begin{array}{c}0.014 \\
(0.016)\end{array}$ & $\begin{array}{l}-0.0003^{*} \\
(0.0002)\end{array}$ & $\begin{array}{c}0.013 \\
(0.018)\end{array}$ & $\begin{array}{c}0.013 \\
(0.016)\end{array}$ \\
\hline Age $^{2} / 10,000$ & $\begin{array}{c}0.013^{*} \\
(0.0073)\end{array}$ & $\begin{array}{c}-1.19 \\
(0.955)\end{array}$ & $\begin{array}{c}-1.19 \\
(0.679)\end{array}$ & $\begin{array}{c}0.011 \\
(0.0074)\end{array}$ & $\begin{array}{c}-1.26 \\
(0.969)\end{array}$ & $\begin{array}{l}-1.27^{*} \\
(0.698)\end{array}$ \\
\hline Limited liability \# & $\begin{array}{c}-0.023^{* *} \\
(0.011)\end{array}$ & $\begin{array}{c}0.613 \\
(0.905)\end{array}$ & $\begin{array}{c}0.584 \\
(0.874)\end{array}$ & $\begin{array}{c}-0.026^{* *} \\
(0.011)\end{array}$ & $\begin{array}{c}0.740 \\
(0.944)\end{array}$ & $\begin{array}{c}0.759 \\
(0.876)\end{array}$ \\
\hline West Germany \# & $\begin{array}{c}-0.043^{* * *} \\
(0.016)\end{array}$ & $\begin{array}{c}1.31 \\
(1.15)\end{array}$ & $\begin{array}{c}1.25 \\
(1.06)\end{array}$ & $\begin{array}{c}-0.047^{* * *} \\
(0.016)\end{array}$ & $\begin{array}{c}1.62 \\
(1.18)\end{array}$ & $\begin{array}{c}1.66 \\
(1.06)\end{array}$ \\
\hline $\begin{array}{l}\text { Support program \# } \\
\text { Inverse Mills ratio }\end{array}$ & $\begin{array}{c}-0.040 * * * \\
(0.0090)\end{array}$ & $\begin{array}{c}2.77 * * * \\
(0.835) \\
-0.471 \\
(3.26) \\
\end{array}$ & $\begin{array}{c}2.73^{* * *} \\
(0.757)\end{array}$ & $\begin{array}{c}-0.040^{* * *} \\
(0.009)\end{array}$ & $\begin{array}{c}3.00 * * * \\
(0.798) \\
0.272 \\
(2.77) \\
\end{array}$ & $\begin{array}{c}3.03 * * * \\
(0.758)\end{array}$ \\
\hline $\begin{array}{l}\text { Observations } \\
\text { Pseudo R-squared } \\
\text { Log likelihood } \\
\text { Rho }\end{array}$ & $\begin{array}{c}4606 \\
0.145 \\
-1052.5\end{array}$ & $\begin{array}{c}4606 \\
0.054 \\
-7007.9 \\
-0.030 \\
\end{array}$ & $\begin{array}{c}4606 \\
0.053 \\
-7007.9\end{array}$ & $\begin{array}{c}4602 \\
0.151 \\
-1027.7\end{array}$ & $\begin{array}{c}4602 \\
0.053 \\
-7008.3 \\
0.017 \\
\end{array}$ & $\begin{array}{c}4602 \\
0.053 \\
-7008.3\end{array}$ \\
\hline
\end{tabular}

Note: Average marginal effects and their standard errors are shown. Marginal effects for the dummy variables (denoted with \#) are calculated for a change from zero to one. The marginal effects of the interaction terms take the simultaneous change of both dummy variables from zero to one into account. All estimates contain the income at district level, dummies for district type, industry dummies at the 2-digit SIC level and year dummies. Standard errors are robust to within company correlation and to heteroscedasticity. Standard errors for columns 2 and 5 are estimated with bootstrapping with 400 replications. ***, **, and * indicate statistical significance at the $1 \%, 5 \%$, and $10 \%$ levels, respectively. 
Table 4: Basic Results for Financing Mix of Actual Investment (Loan Denial A)

\begin{tabular}{|c|c|c|c|c|}
\hline \multicolumn{5}{|c|}{ Panel A } \\
\hline & \multicolumn{2}{|c|}{ Innovator } & \multicolumn{2}{|c|}{ Non-innovator } \\
\hline & $\begin{array}{l}\text { No loan denial } \\
(\text { Loan denial } A=0)\end{array}$ & $\begin{array}{c}\text { Loan denial } \\
(\text { Loan denial } \mathrm{A}=1)\end{array}$ & $\begin{array}{c}\text { No loan denial } \\
(\text { Loan denial } A=0)\end{array}$ & $\begin{array}{c}\text { Loan denial } \\
(\text { Loan denial } A=1)\end{array}$ \\
\hline External equity & 1.1 & 6.7 & 0.2 & 0.2 \\
\hline Mezzanine capital & 2.1 & 2.2 & 1.2 & 0.6 \\
\hline Bank loans & 43.1 & 41.7 & 53.4 & 54.6 \\
\hline Internal funds & 29.8 & 25.2 & 23.0 & 23.1 \\
\hline Public funds & 18.2 & 14.0 & 20.2 & 17.6 \\
\hline Other & 5.7 & 10.2 & 2.0 & 5.0 \\
\hline \multicolumn{5}{|c|}{ Panel B } \\
\hline & \multicolumn{2}{|c|}{ Occasional or continuous R\&D } & \multicolumn{2}{|c|}{ No R\&D } \\
\hline & $\begin{array}{c}\text { No loan denial } \\
(\text { Loan denial } \mathrm{A}=0 \text { ) }\end{array}$ & $\begin{array}{c}\text { Loan denial } \\
(\text { Loan denial } \mathrm{A}=1)\end{array}$ & $\begin{array}{c}\text { No loan denial } \\
(\text { Loan denial } A=0)\end{array}$ & $\begin{array}{c}\text { Loan denial } \\
(\text { Loan denial } A=1)\end{array}$ \\
\hline External equity & 0.7 & 9.2 & 1.0 & 1.9 \\
\hline Mezzanine capital & 2.6 & 3.1 & 1.3 & 0.5 \\
\hline Bank loans & 40.8 & 34.2 & 49.4 & 55.4 \\
\hline Internal funds & 30.5 & 24.4 & 26.2 & 25.0 \\
\hline Public funds & 18.9 & 17.9 & 18.8 & 10.7 \\
\hline Other & 6.6 & 11.3 & 3.3 & 6.9 \\
\hline
\end{tabular}

Note: The financing shares are weighted with the investment volume and thus reflect the overall importance of the different financing sources in the sample. The calculation is based on 4,387 observations for the category innovator and on 4,431 observations for the category R\&D type. 
Table 5: Robustness Check for Financing Mix of Actual Investment (Loan Denial B)

\begin{tabular}{|c|c|c|c|c|}
\hline \multicolumn{5}{|c|}{ Panel A } \\
\hline & \multicolumn{2}{|c|}{ Innovator } & \multicolumn{2}{|c|}{ Non-innovator } \\
\hline & $\begin{array}{l}\text { No loan denial } \\
(\text { Loan denial } \mathrm{B}=0)\end{array}$ & $\begin{array}{c}\text { Loan denial } \\
(\text { Loan denial B }=1)\end{array}$ & $\begin{array}{l}\text { No loan denial } \\
(\text { Loan denial } \mathrm{B}=0)\end{array}$ & $\begin{array}{c}\text { Loan denial } \\
(\text { Loan denial } \mathrm{B}=1)\end{array}$ \\
\hline External equity & 1.2 & 16.4 & 0.2 & 0.3 \\
\hline Mezzanine capital & 2.1 & 2.1 & 1.2 & 2.3 \\
\hline Bank loans & 43.4 & 16.6 & 53.7 & 32.1 \\
\hline Internal funds & 29.4 & 36.7 & 22.8 & 47.3 \\
\hline Public funds & 18.1 & 10.0 & 20.2 & 1.7 \\
\hline Other & 5.8 & 18.2 & 2.0 & 16.3 \\
\hline \multicolumn{5}{|c|}{ Panel B } \\
\hline & \multicolumn{2}{|c|}{ Occasional or continuous $R \& D$} & \multicolumn{2}{|c|}{ No R\&D } \\
\hline & $\begin{array}{l}\text { No loan denial } \\
(\text { Loan denial } \mathrm{B}=0 \text { ) }\end{array}$ & $\begin{array}{c}\text { Loan denial } \\
(\text { Loan denial } \mathrm{B}=1 \text { ) }\end{array}$ & $\begin{array}{l}\text { No loan denial } \\
(\text { Loan denial } \mathrm{B}=0 \text { ) }\end{array}$ & $\begin{array}{c}\text { Loan denial } \\
(\text { Loan denial } \mathrm{B}=1)\end{array}$ \\
\hline External equity & 0.9 & 19.3 & 1.0 & 3.3 \\
\hline Mezzanine capital & 2.7 & 1.9 & 1.3 & 2.6 \\
\hline Bank loans & 40.8 & 14.6 & 50.0 & 27.7 \\
\hline Internal funds & 30.1 & 33.1 & 25.9 & 48.1 \\
\hline Public funds & 19.0 & 9.0 & 18.5 & 7.6 \\
\hline Other & 6.6 & 22.0 & 3.4 & 10.6 \\
\hline
\end{tabular}

Note: The financing shares are weighted with the investment volume and thus reflect the overall importance of the different financing sources in the sample. The calculation is based on 4,403 observations for the category innovator and on 4,448 observations for the category R\&D type. 
Figure A1: Sample Selection and Structure of Available Information

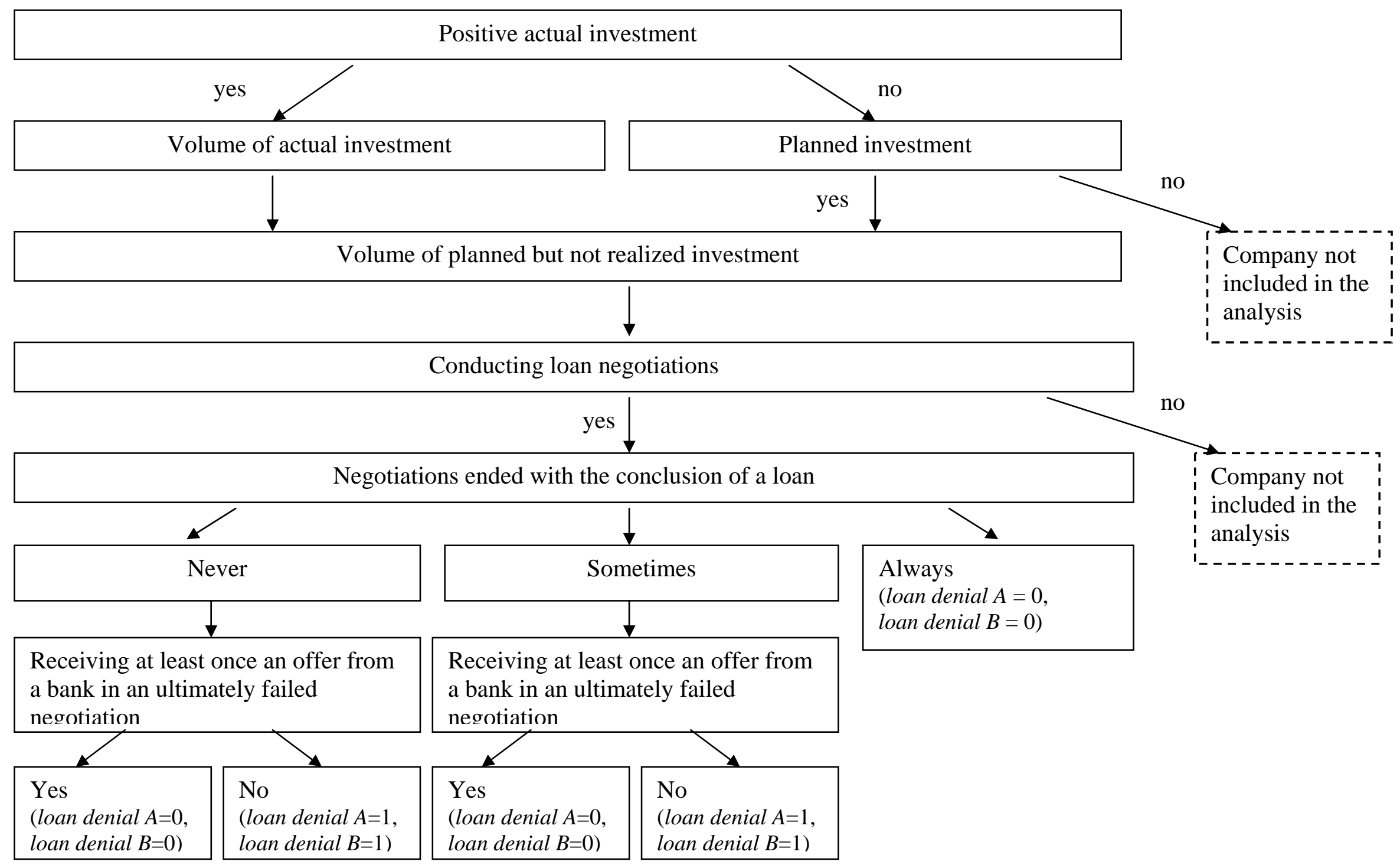




\section{References}

Audretsch, D. and Elston, J. A. (2002), Does Firm Size Matter? Evidence on the Impact of Liquidity Constraints on Firm Investment Behavior in Germany, International Journal of Industrial Organization, 20, 1-17.

Berger, A. N. and Udell, G. F. (1998), The Economics of Small Business Finance: The Roles of Private Equity and Debt Markets in the Financial Growth Cycle, Journal of Banking and Finance, 22, 613-673.

Bhattacharya, S. and Ritter, J. R. (1983), Innovation and Communication: Signalling with Partial Disclosure, Review of Economic Studies, 50, 331-346.

Bond, S., Harhofff, D. and Van Reenen, J. (2006), Investment, R\&D and Financial Constraints in Britain and Germany, Annales d'Économie et de Statistique, forthcoming. BVK (2006), BVK Statistik 2005, German Private Equity and Venture Capital Association (BVK), Berlin, www.bvk-ev.de.

Czarnitzki, D. (2006), Research and Development in Small and Medium-Sized Enterprises: The Role of Financial Constraints and Public Funding, Scottish Journal of Political Economy, 53, 335-257.

Delbreil, M., Esteban, A., Foulcher, S., Elgg, D., Favale, V., Körting, T., and Varetto, F. (2005), Net Worth at Risk, European Committee of Central Balance Sheet Data Offices.

Dell’Ariccia, G., Detragiache, E. and Rajan, R. (2008), The Real Effect of Banking Crises, Journal of Financial Intermediation, 17, 89-112.

Engel D. and Middendorf, T. (2009), Investment, Internal Funds and Public Banking in Germany, Journal of Banking and Finance, 33, 2132-2139.

Freel, M. (2007), Are Small Innovators Credit Rationed?, Small Business Economics, 28, 2345.

Gan, J. (2007a), Collateral, Debt Capacity, and Corporate Investment: Evidence from a Natural Experiment, Journal of Financial Economics, 85, 709-734.

Gan, J. (2007b), The Real Effects of Asset Market Bubbles: Loan- and Firm-Level Evidence of a Lending Channel, Review of Financial Studies, 20, 1941-1973. 
Gatchev, V. A., Spindt, P. A. and Tarhan, V. (2009), How Do Firms Finance Their Investments? The Relative Importance of Equity Issuance and Debt Contracting Costs, Journal of Corporate Finance, 15, 179-195.

Gibson, M. S. (1995), Can Bank Health Affect Investment? Evidence from Japan, Journal of Business, 68, 281-308.

Gompers, P. (1995), Optimal Investment, Monitoring, and the Staging of Venture Capital, Journal of Finance, 50, 1461-1489.

Guiso, L. (1998), High-tech Firms and Credit Rationing, Journal of Economic Behavior and Organization, 35, 39-59.

Hall, B. (1992), Investment and Research and Development at the Firm Level: Does the Source of Financing Matter?, NBER Working Paper No. 4096.

Hall, B. (2002), The Financing of Research and Development, Oxford Review of Economic Policy, 18, 35-51.

Hancock, D. and, Wilcox, J. A. (1998), The 'Credit Crunch' and the Availability of Credit to Small Business, Journal of Banking and Finance, 22, 983-1014.

Heckman J. J. (1976), The Common Structure of Statistical Models of Truncation, Sample Selection and Limited Dependent Variables and a Simple Estimator for Such Models, Annals of Economic and Social Measurement, 5, 475-492.

Himmelberg, C. and Petersen, B. (1994), R\&D and internal finance: A panel study of small firms in high-tech industries, Review of Economics and Statistics, 76, 38-51.

Hottenrott, H. and Peters, B. (2009), Innovative Capability and Financing Constraints for Innovation - More Money, More Innovation?, ZEW Discussion Paper No. 09-081.

Hubbard, R. G. (1998), Capital-market Imperfections and Investment, Journal of Economic Literature, 36, 193-225.

Kaplan, S. and Stromberg, P. (2003), Financial Contracting Theory Meets the Real World: Evidence from Venture Capital Contracts, Review of Economic Studies, 70, 281-315.

Kortum, S. and Lerner, J. (2000), Assessing the Contribution of Venture Capital to Innovation, RAND Journal of Economics, 31, 674-692. 
Li, K. and Prabhala, N. R. (2006), Self-Selection Models in Corporate Finance, in Eckbo, E. (ed.), Handbook of Corporate Finance: Empirical Corporate Finance, Chapter 2, Elsevier/North Holland, 37-86

Martin, J. S. and Santomero, A. M. (1997), Investment Opportunities and Corporate Demand for Lines of Credit, Journal of Banking and Finance, 21, 1331-1350.

Modigliani, F. and Miller, M. (1958), The Cost of Capital, Corporation Finance, and the Theory of Investment, American Economic Review, 48, 261-297.

Mueller, E. and Zimmermann, V. (2009), The Importance of Equity Finance for R\&D Activity - Are There Differences Between Young and Old Companies?, Small Business Economics, 33, 303-318.

Myers, S. C. and Majluf, N. (1984), Corporate Financing and Investment Decisions When Firms have Information that Investors do not have, Journal of Financial Economics, 13, 187-221.

Rammer, C., Müller, E., Heger, D., Aschhoff, B., Zimmermann, V. and Reize, F. (2006), Innovationspotenziale von kleinen und mittleren Unternehmen [The Innovative Potential of Small and Medium-sized Enterprises], ZEW Wirtschaftsanalysen, Vol. 79, BadenBaden.

Reize, F. (2007), KfW-Mittelstandspanel 2007, Mittelstand im Konjunkturhoch - Defizite bei Innovationen [KfW Panel of Medium-sized Companies 2007, Medium-sized Companies in the Boom Period - Innovation with Deficits], KfW Bankengruppe, Frankfurt am Main.

Reize, F. and Lo, V. (2008), KfW-Mittelstandspanel 2008, Mittelstand - auch kleine Unternehmen - erfolgreich im Ausland! [KfW Panel of Medium-sized Companies 2008, Medium-sized Companies - Also Small Ones - Successful Abroad!], KfW Bankengruppe, Frankfurt am Main.

Reize, F. and Zimmermann, V. (2009), KfW-Mittelstandspanel 2009, 2008 - Wirtschaftskrise erfasst auch Mittelstand: Investitionen steigen noch. Aber Innovationen lassen nach [KfW Panel of Medium-sized Companies 2009, 2008 Economic Crisis Seizes Mittelstand: Still Increasing Investments. But Decreasing Innovation], KfW Bankengruppe, Frankfurt am Main.

Stiglitz, J. and Weiss, A. (1981), Credit Rationing in Markets with Imperfect Information, American Economic Review, 71, 393-410. 
Winker, P. (1999), Causes and Effects of Financing Constraints at the Firm Level, Small Business Economics, 12, 169-188.

Wooldridge, J. M. (2002), Econometric Analysis of Cross Section and Panel Data, MIT Press, Cambridge, Massachusetts. 